\title{
HERMENÊUTICA TEOLÓGICA: CAMINHO PARA A AFIRMAÇÃO DA IDENTIDADE RELIGIOSA ${ }^{1}$
}

\author{
Walter Ferreira Salles*e Deivison Rodrigo do Amaral**
}

\section{RESUMO}

O horizonte a partir do qual se constrói o presente ensaio é o do diálogo entre judaísmo e cristianismo, tendo por pressuposto que a identidade religiosa é também uma identidade fundamentada nos textos da tradição. A reflexão que propomos neste ensaio tem por referencial teórico o entrelaçamento entre mundo do texto e de identidade narrativa, noções oriundas da hermenêutica filosófica de Paul Ricoeur. Em outras palavras, a construção da própria identidade

\begin{abstract}
This article is based upon the dialogue between Judaism and Christianity, assuming that religious identity arises from - besides other elements - the Traditional texts. The reflection we propose uses the relationship between the world of the text and the narrative identity, these concepts taken from philosophical hermeneutics by Paul Ricoeur. In other words, the creation of religious identity supposes the hermeneutics of oneself on the mirror of the words,
\end{abstract}

1 O presente trabalho reúne reflexões oriundas do Projeto de Iniciação Científica do aluno de teologia Deivison Rodrigo do Amaral, que fez parte do Projeto de Pesquisa "Identidade narrativa e linguagem religiosa. A ontologia hermenêutica de Paul Ricoeur como princípio de análise do pluralismo religioso", do Prof. Walter Salles, desenvolvido no biênio 2008-2009 na PUC-Campinas. Esse projeto de Iniciação Científica teve por objetivo refletir sobre o diálogo entre o Judaísmo e o Cristianismo, tendo por pressuposto que a identidade religiosa é também uma identidade textual.

* Walter Ferreira Salles possui graduação em Filosofia pela Faculdade Jesuíta de Filosofia e Teologia (1990), graduação em Teologia pela Faculdade Jesuíta de Filosofia e Teologia (1995), mestrado em Teologia pelo Centre Sèvres - França (1997) e doutorado em Ciências da Religião pela Universidade Metodista de São Paulo (2006). Professor em regime de dedicação integral na Pontifícia Universidade Católica de Campinas. Tem experiência nas áreas de Teologia e de Filosofia, com ênfase em Hermenêutica, Antropologia Teológica, Ciências da Religião.

** Deivison Rodrigo do Amaral possui graduação em Filosofia pela Pontifícia Universidade Católica de Campinas (2007). Atualmente cursando o terceiro ano da Faculdade de Teologia na mesma Universidade e integrante do grupo de Iniciação Científica sobre Teologia Contemporânea. 
religiosa supõe a hermenêutica de si no espelho das palavras que são fornecidas pelos textos da tradição. $O$ objetivo, pois, da presente reflexão é perceber como essa hermenêutica de si pode contribuir para com o diálogo entre duas tradições monoteístas que fudamentam suas identidades na leitura dos textos sagrados.

Palavras-chave: hermenêutica, identidade, religião, texto. which are taken from the Traditional texts. The objective of this reflection is to understand how this hermeneutics of the self can contribute to the dialogue between two monotheistic traditions that lay the foundation of their identities on the sacred texts.

Key-words: hermeneutics, identity, religion, text.

\section{INTRODUÇÃO}

O judaísmo e o cristianismo são tidos frequentemente como religiões abraâmicas que, juntamente com o islamismo se configuram como religiões monoteístas, denominadas também de religiões do Livro. As Sagradas Escrituras são tão importantes para essas religiões, que judeus e cristãos as consideram como fonte fundamental da fé professada, insubstituíveis e cultuadas pelos fiéis como Revelação de Deus à humanidade. É dentro deste contexto que emergem conflitos interpretativos. Toda profissão de fé religiosa, judaica ou cristã - abarcando as inúmeras correntes ideológicas com interpretações específicas oriundas dessas religiões -, interfere significativamente na vida social, política e cultural de cada povo e nação.

A possibilidade da convergência entre as tradições abraâmicas, o judaísmo e o cristianismo, é aparentemente improvável se voltarmos nosso olhar para o passado conflituoso que envolve ambas as tradições, improbabilidade que pode inclusive conduzir a uma conclusão precipitada: uma suposta conciliação de opiniões e de interpretações teria provavelmente como consequência principal a perda da identidade religiosa. Contudo, recentes reflexões em torno da hermenêutica filosófica possibilitaram um avanço significativo na compreensão da interpretação de um texto, cujas consequências se fizeram sentir no âmbito teológico, suscitando um amplo diálogo entre tradições religiosas, como é o caso do judaísmo e do cristianismo, que souberam incorporar contribuições oriundas da filosofia. 
Nessa perspectiva, as reflexões do filósofo francês Paul Ricoeur (1913-2005) são de grande importância para o desenvolvimento de uma hermenêutica dos textos sagrados; conciliadora e aberta a novas formas de interpretação, sem que isto signifique a perda do essencial de cada tradição religiosa. Isto porque, a partir da hermenêutica filosófica desenvolvida por Ricoeur, estar sob o risco da interpretação não se restringe à dimensão negativa da ameaça provocada pelo outro diferente de mim. Estar diante do diferente pode significar a rica possibilidade de uma releitura dos fundamentos da própria fé que consequentemente ajude a uma nova interpretação da identidade que dessa fé emana. Mais do que risco no sentido negativo, o pluralismo religioso que nos caracteriza pode configurar-se como a possibilidade de uma nova percepção da identidade religiosa entendida como uma identidade em contínua construção a partir da releitura de textos fundadores.

A reflexão que propomos neste ensaio tem por pressuposto a ideia de que o entrelaçamento entre a noção de mundo do texto e de identidade narrativa, oriundas da hermenêutica filosófica de Paul Ricoeur, pode fundamentar a releitura das identidades religiosas que se fundamentam na leitura interpretativa de textos que são considerados sagrados. Textos que, como gosta de afirmar o próprio Ricoeur, são capazes de possibilitar a decifração da vida e a construção da própria identidade no espelho das palavras. Em outras palavras, a construção da própria identidade religiosa supõe a hermenêutica de si no espelho das palavras que são fornecidas pelos textos da tradição. $O$ objetivo, pois, da presente reflexão é perceber como essa hermenêutica de si pode contribuir para com o diálogo entre as duas tradições abraâmicas.

\section{TRADIÇÕES JUDAICAS E CRISTÃS A PARTIR DA INTERPRETAÇÃO DO LIVRO}

No tocante ao processo dialógico, torna-se essencial a análise da construção de uma tradição, especialmente no que tange à sua interpretação de mundo a partir do seu contexto histórico específico. Isto porque é a partir da afirmação de uma identidade, na preservação de sua expressão cultural sob os meandros de sua gênese, que se estabelece um profícuo diálogo que remete à abertura ao outro diferente de mim, o que, por sua 
vez, poderá possibilitar uma conciliação de afirmações contrárias e não uma sujeição argumentativa.

Deste modo, para o estudo hermenêutico é necessário ressaltar que tanto a cultura judaica (rabínica) quanto a cultura cristã advém de uma mesma raiz histórica e religiosa, e que ambas nascem sob um mesmo panorama social. Contudo, cada qual se posiciona interpretativamente a partir de paradigmas próprios, sendo que esses foram grandes meios que impulsionaram as perspectivas e esperanças religiosas, levando-as a adquirirem identidade e formas cultuais distintas.

Os textos qumrãnicos ${ }^{2}$ especificamente os manuscritos de interpretação das Escrituras, são certamente um grande facilitador para a compreensão dessa identidade originária comum a essas duas grandes religiões monoteístas. Tais descobertas arqueológicas foram de grande importância devido à iluminação que propiciaram ao campo da interpretação e exegese bíblicas. Luz que orientou grande parte das pesquisas hermenêuticas recentes, proporcionando, além de uma profunda interação entre os estudiosos judeus e cristãos, um avanço do estudo hermenêutico no campo bíblico, já que tais manuscritos referem-se diretamente aos primórdios dessas duas grandes tradições religiosas monoteístas.

Por isso, o estudo arqueológico desses achados e o desenvolvimento da hermenêutica textual têm legado aos exegetas contemporâneos informações mais precisas para a interpretação das Escrituras, propiciando a todos uma postura mais receptiva ao diálogo e ao trabalho em conjunto. Esses achados explicitaram, em sua época, uma dupla finalidade hermenêutica, convergente com o anseio atual dos biblistas: inteligibilidade e coerência textual, e aplicação do texto a novas situações recorrentes à atualidade. ${ }^{3}$

\section{HERMENÊUTICA RABÍNICA E SUA RELAÇÃO COM A HERMENÊUTICA CRISTÃ}

\footnotetext{
2 Os denominados manuscritos de Qumrã são fragmentos de textos que datam dos primórdios da era cristã, descobertos em Israel na década de 1940. Tais fragmentos, conhecidos como escritos do Mar Morto, rememoram a antiga comunidade essênia de Qumrã e são de importantíssimo valor arqueológico e religioso para o atual estudo da exegese bíblica.

3 Júlio Trebolle BARRERA, Os Homens de Qumran, p.141.
} 
A hermenêutica rabínica ${ }^{4}$ tem sua grande inspiração na tradição denominada judaísmo do segundo Templo, que possuía três pilares fundamentais: o estudo e interpretação da Torá, a observância das prescrições cultuais e a esperança messiânica. A fundamentação desse novo modelo hermenêutico foi possível, em parte, devido à destruição do Templo, ${ }^{5}$ marco referencial dessa nova postura religiosa, o que possibilitou ao judaísmo desenvolver-se a partir de uma nova perspectiva denominada meta-histórica, com acento no eterno e imutável da vida, regulamentada pela Torá de acordo com a exegese rabínica. Esta nova postura no seio do judaísmo significou, de certo modo, o abandono de sua trajetória anterior na direção histórico-messiânica, a qual encontrará maior desenvolvimento no cristianismo.

Assim como o cristianismo, o judaísmo tem sua base hermenêutica na interpretação da Escritura. Deste modo, conceitos-chave desta hermenêutica precisam ser compreendidos, os quais o autor Júlio T. Barrera ${ }^{6}$ subdivide em: midraxe, halacá e hagadá. Por midraxe entende-se o estudo dos textos sagrados com finalidade homilética, ou seja, a busca para encontrar o máximo de exemplos edificantes por meio de uma meditação dos textos sagrados, por vezes utilizando-se de uma reconstrução imaginária do lugar e do episódio narrado, tendo por objetivo interpretá-los sempre visando à aplicação prática do texto à realidade ${ }^{7}$. Contudo, sem uma finalidade "operacional" específica, assim como a halacá e hagadá, que são caracterizadas por suas distintas especificidades dentro da cultura judaica.

4 Para o estudo da Hermenêutica rabínica, foi utilizada a seguinte obra: BARRERA, J. T. A bíblia judaica e a bíblia cristã. Introdução à história da Bíblia. Petrópolis: Vozes, 1995.

5 A destruição do Templo no final da revolta judaica (66-70d.C.), que desencadeia um movimento de desaparecimento e de dispersão, traz como consequência a reorganização consciente e ordenada do povo em torno da Torá. A literatura rabínica passa pelo controle do colégio dos mestres. É importante ressaltar que a destruição do Templo significa consequentemente o desaparecimento da liturgia sacrificial, que constituía, até então, uma referência profundamente significativa na vida do povo de Israel. Não se perde a Tradição como um todo, mas sim sua continuidade por meio dessa nova corrente (judaísmo) de mestres e discípulos, e pela execução de procedimentos redacionais bem controlados.

6 Júlio Trebolle Barrera é membro do Comitê internacional de plublicação dos manuscritos do Mar Morto, é autor de vários livros de crítica textual, crítica literária da Bíblia e hermenêutica bíblica contemporânea. É professor do Departamento de Estudios Hebreus y Arameus e doutor em Filologia Semítica e Teologia, licenciado em Filosofia Pura e Ciências Bíblicas e élève honoraire de L'École Biblique de Jerusalém.

7 John MCKENZIE, Dicionário Bíblico, pp. 609-610. 
A halacá é um desenvolvimento da legislação bíblica, característica da literatura da época mixnaica. ${ }^{8}$ Segundo Barrera, "ela pretendia governar todos os âmbitos da vida, desde o amanhecer até o anoitecer, desde o nascimento até à morte, alargando-se inclusive para além do povo judeu, ou seja, à humanidade inteira por meio dos chamados preceitos noáquicos". ${ }^{9}$ Por isso assume característica jurídica em sua interpretação dos livros bíblicos. Como exemplo de seu caráter legislativo em seu período de maior desenvolvimento, a época persa, no início da época helenística, temos a proibição do matrimônio com mulheres estrangeiras. Esta proibição não teve sua origem no midraxe, mas na administração da justiça, pois antes isto não era assunto de sábios exegetas, mas de sábios juízes nos tribunais. Assim sendo, a halacá pode ser caracterizada a partir de duas vias: a midráxica e a independente da Escritura, uma vez que a primeira relaciona-se com o mundo do estudo da Torá e a segunda com a prática jurídica, contudo não dissociadas entre si. ${ }^{10}$ Já a hagadá consistia em um caráter ético-teológico da interpretação das escrituras.

Diante da relevância das noções terminológicas da hermenêutica judaica, é importante considerar alguns aspectos das escolas a partir das quais tais noções se desenvolveram. Dentre estas escolas, sem dúvida, uma das mais consideráveis é a escola de Hillel, ${ }^{11}$ a qual promulgava normas e ensinava doutrinas baseando-se mais na lógica e na dedução racional do que na tradição e nas autoritates. Ele estabeleceu sete regras com o objetivo de regerem toda interpretação legal e exegética dos textos bíblicos. Para isso, fez uso de modelos e termos técnicos de retórica helenística. Com tal objetivo, utilizando a lógica e os métodos hermenêuticos gregos, introduziu no

8 Mishná: a palavra quer dizer o que é ensinado ou estudado através da repetição oral. Em sentido amplo, designa o conjunto da Torá oral. Em sentido mais restrito, a compilação mais antiga da tradição farisaica, apresentada de forma oral.

9 São preceitos que retomam a história bíblica do dilúvio na figura de Noé, descritas por sacerdotes no cativeiro da Babilônia, considerando-o o expoente de uma aliança universal, não apenas do povo eleito, mas uma aliança de amor com toda a humanidade.

10 Segundo Barrera, o midraxe é a fonte de criação da halacá; não se restringe a um serviço legal de aprovação de uma lei baseada na Escritura, nem tampouco a uma pura atividade exegética.

11 Hillel é procedente da Babilônia; seus mestres eram alexandrinos. Na Palestina gozou da simpatia dos herodianos, pelo fato de não se deixar fascinar pelas especulações apocalípticas nem tampouco pelos impulsos de caráter messiânico. Viveu em uma época de transição e intensas mudanças durante o período herodiano, na qual os sistemas legais e as instituições jurídicas entraram em crise e em muito perderam suas forças coercitivas. 
direito e no pensamento hebraico o princípio do realismo socrático e estoico, além de um método de por em questão ${ }^{12}$ até o mais óbvio. Criou também condições de possibilidade para o controle racional da Torá, considerando que a interpretação e a aplicação da lei em seu sentido literal podem, em determinados momentos, contradizerem o verdadeiro espírito da lei, pois as circunstâncias históricas para quais as leis foram criadas mudaram. Sendo assim, ele promulgou decretos taqqanôt ${ }^{13}$ os quais em cada caso seguiam determinações momentâneas. Com isso, não se importava em mudar, se preciso, a literalidade do texto, desde que salvaguardasse o sentido e o fim primordial da mesma.

Diante da reprovação dos rigoristas, Hillel defendia que sua interpretação racional tornava possível preservar a validade e a aplicabilidade da lei a novos tempos e lugares da diáspora, do contrário não seria aceitável a aplicação de leis de tempos remotos, pensadas para o âmbito de Israel. Ao mesmo tempo em que assumia a tradição recebida, a escola de Hillel recolhia e dava valor jurídico à práxis, sem perguntar se a origem de um costume adquirido poderia ser alheia à tradição de Israel. Tal simbiose entre tradição e modernidade tornou-se possível pelo trabalho de interpretação e de atualização dos antigos textos da Sagrada Escritura. O uso ou costume convertia-se em halacá e legalizado era considerado sagrado; com essa atitude assegurava-se que o cumprimento da lei estivesse ao alcance de todo o povo judeu, não se convertendo em privilégio de eleitos e de perfeitos.

Paralelamente à escola hillelita, existia a escola de Shammai. Este era detentor de uma posição mais conservadora, patriótica, oposto aos influxos estrangeiros. Embora tão diferentes entre si no campo ideológico, as duas escolas se equivaliam e pouco discordavam na questão da abertura à interpretação. Embora Shammai fosse mais rigorista, sua opinião é ser mais aberta, pois ele revela a preocupação em salvaguardar os princípios fundamentais em vez de uma intransigência absoluta na aplicação das leis. No campo teológico a perspectiva de Shammai era mais teocêntrica, ao passo que Hillel era mais antropocêntrica.

12 De acordo com Barrera, "a utilização da lógica e dos métodos hermenêuticos gregos introduziu no direito e no pensamento hebraico o princípio do realismo socrático e estoico e uma disposição dialógica de colocar em questão até o mais óbvio". A Bíblia judaica e a bíblia cristã, p. 565.

13 Regulamentos específicos para a proteção do sentido genuíno da lei. 
Outras duas escolas são de grande importância para o resgate do estudo hermenêutico rabínico: as escolas de R. Ismael e de R. Aqiba; ambas representam duas grandes correntes opostas. A hermenêutica de R. Ismael partia do pressuposto de que toda doutrina ou lei vem expressa em linguagem humana, e portanto sua interpretação tem que ser regida pela lógica da razão, assim como Hillel na promulgação de novas leis em função das circunstâncias ante a derivação das leis a partir dos textos da Escritura. Na escola de R. Ismael a interpretação estava dotada de grande rigor crítico, filológico e histórico. Já Aqiba dava primazia à derivação de leis a partir dos textos sagrados, não deixando espaço para a halacá pura e a criação de novas taqqanôt. Para ele, toda tradição oral poderia ser legitimada pela escritura.

O cristianismo, ao contrário do judaísmo, sobretudo com Paulo e João, aproximou-se mais das correntes essênias afastando-se do farisaísmo hillelita. A tradição cristã tendeu a estabelecer limites em seu terreno doutrinal desde cedo, contra as necessidades de adaptar-se a mundos culturais diferentes e plurais, coisa que não acontecia com o judaísmo, pois era mais indulgente a partir de sua dialógica estrutura hermenêutica, o qual elaborava novas halacás para garantir a coesão e a sobrevivência do corpo social judeu.

No que tange à estrutura hermenêutica rabínica, especialmente a hilleliana, é possível dizer que correspondia a um estilo dialógico que favorecia e alentava o pluralismo de opiniões e de perspectivas, pois o debate rabínico estava sempre inacabado e aberto à discussão. A argumentação podia ser mais importante que as conclusões extraídas, uma vez que a verdade é considerada sempre inatingível, tendo a razão um lugar de destaque no campo hermenêutico. Sua teologia (judaica) não se cristalizava em dogmas; no máximo uma defesa contra o gnosticismo; buscava sempre ressaltar o monoteísmo e a bondade da criação. De grande espírito crítico, tal hermenêutica não se abstraía de julgar até mesmo Deus. Tradição e Revelação são categorias fundamentais que, no judaísmo, se encontram em profunda sintonia, já que a tradição é transmitida pela geração de um sentido novo e pela renovação de um sentido antigo. Essa renovação, hiddûs, ${ }^{14}$ é enriquecedora graças a sua contínua atualização.

14 Transmissão da tradição judaica por meio de uma renovação linguística que não altera a integridade do dado textual. 
Barrera salienta que a hermenêutica judaica possui quatro gêneros de interpretação: a interpretação literal peshat, mais presente na literatura midráxica que na talmúdica; a profética pesher, para a qual o sentido do texto sagrado não corresponde às circunstâncias do momento no qual foi escrito, mas ao sentido profético que o texto adquire por referência às circunstâncias da comunidade escatológica, como a comunidade de Qumrã; a derash e a midrash referem-se à midraxe, que, por sua vez, designa realidades diferentes: a derash, como procedimento exegético pelo qual se interpreta um texto, e a midrash, que correspondia à possibilidade de utilizar diferentes estilos para levar com eficácia a mensagem da Escritura, ou o propósito de resolver alguns problemas e contradições no texto, mantendo vivo o espírito de comunidade e até mesmo aprofundar o sentido da Escritura, a fim de propiciar uma integração com as outras culturas, como, por exemplo, o estudo da figura de Esaú..$^{15} \mathrm{O}$ midraxe tem aqui a função de descobrir os recônditos do texto, ao passo que a alegoria, como modelo helênico de literatura, recorria ao caráter filosófico e retórico da cultura grega.

Os gêneros hermenêuticos aludem a regras e métodos interpretativos. Tais métodos têm por base as regras hillelianas, as quais são desenvolvidas em sua escola por seus discípulos. Essas regras conduziram a um desenvolvimento exegético atomizador, ou seja, que interpretava sentenças, cláusulas, frases e até mesmo palavras soltas com absoluta independência do contexto literário e das circunstâncias históricas aludidas no texto, sendo mais aplicadas em temas da hagadá. É importante compreender também que a interpretação rabínica não explica os simples sinais genericamente, mas os que se encontram em um determinado texto; a ordem ou a sequência das letras, palavras ou frases podem ser portadores de sentido. Assim,

na exegese rabínica o sentido não é nunca imediato. A palavra revelada espera uma aplicação para ser compreendida. $O$ comentário é por isso sempre necessário e a exegese se inscreve dentro de uma longa tradição. $O$ texto não existe senão na caixa

15 Esaú, o irmão de Jacó/Israel, converte-se também em símbolo do Cristianismo, que se considera herdeiro das promessas judaicas e se apossa também da herança do Império Romano. Através da figura de Esaú, o midraxe reconhece o parentesco que une Judaísmo e Cristianismo, porém faz saber ao mesmo tempo que o Cristianismo, associado ao Império Romano, terminará cedendo lugar aos filhos da bênção confiada aos israelitas descendentes de Jacó. 
de ressonância da tradição. Estar ancorado em uma tradição não significa estar submisso a preconceitos que limitam a liberdade. É pôr-se à escuta, criar-se uma estrutura de antecipação que permita acercar-se ao texto e compreendê-lo. ${ }^{16}$

No judaísmo toda interpretação é aplicação, isto é, aplicação de uma norma legal a um caso particular na halacá, e aplicação de uma norma ético-religiosa, escrita ou oral, a novas circunstâncias e lugares na hagadá. A hermenêutica tem caráter dialogal e dialogante, o qual apresenta uma estrutura circular de pergunta-resposta. A essência do diálogo radica não tanto na relação estabelecida na discussão entre os intérpretes, mas na relação, também dialógica, que estes tratam de estabelecer com o texto e com o que o texto pretende desvelar: a Torá eterna e a vontade divina.

Detentora de uma mesma aspiração, a hermenêutica cristã em seus primórdios utilizou os princípios e métodos exegéticos judaicos para o desenvolvimento de sua exegese, mas a partir de uma leitura cristológica dos textos veterotestamentários. Os escritos neotestamentários apresentam forte influência do judaísmo qumrânico, assemelhando-se mais às suas formas apocalípticas do que à estrutura do judaísmo rabínico, visto que os primórdios do cristianismo advêm do movimento jesuânico que é notadamente apocalíptico em seu anúncio. Este traço marcante da estrutura hermenêutica cristã encaminha-a a um novo modelo religioso, demarcando, assim, a distinção entre ambas as interpretações, sem, contudo, perderem a grande matriz que é o Antigo Testamento, embora relido sob duas novas formas e a partir modelos sociais distintos.

\section{JUDAÍSMO E CRISTIANISMO: \\ MESMA FONTE MAS DUAS PERSPECTIVAS}

A pluralidade das mais diversas instâncias sociais é um marco da sociedade contemporânea, caracterizada por intensas transformações culturais, sendo notável sua manifestação no conturbado panorama do campo religioso. Tal ponderação pode ser constatada na intensificação da subjetividade da fé, já que é possível observar um considerável aumento de pessoas que professam sua fé sem necessariamente pertencerem a uma denominação

16 Júlio Trebolle BARRERA, A bíblia judaica e a bíblia cristã, p. 578. 
religiosa, e até mesmo um considerável aumento de ateus e agnósticos. $\mathrm{E}$ nesse mesmo processo há um considerável crescimento do fundamentalismo na prática religiosa de várias denominações, o que dificulta as relações sociais necessárias tendo em vista o diálogo e o respeito mútuo. Deste modo, a afirmação da identidade religiosa nesse conturbado contexto pode denotar atitudes de segregação e intolerância capazes de romper profundamente com o papel que cada tradição religiosa possui na sociedade: integradora social, cultural e espiritual.

No tocante ao judaísmo e ao cristianismo, e suas consideráveis influências na cultura ocidental, é possível verificar pontos em comum que, em direção contrária ao fluxo crescente de particularização da fé e de posições extremistas excludentes, apresentam substratos teológicos capazes de inserir as duas tradições em um fecundo e aberto diálogo. E isto a partir de um "lugar comum", a Sagrada Escritura, considerada como Revelação divina e comunicação de Deus com a humanidade. Sendo assim, é cabível salientar a importância de um retorno às origens, a fim de identificar a proximidade que existe entre ambas as tradições religiosas, com base na perspectiva hermenêutica. De tal modo que não se promova a perda da própria identidade cultural e religiosa, mas que se enfatize o enfoque teológico que torna essas religiões co-herdeiras do mesmo princípio de fé: o Deus único criador e salvador.

Com base nessa perspectiva, existe a convergência entre essas duas culturas religiosas na direção daquilo que Paul Ricoeur define como "mundo do texto", pois a partir da apropriação desse mundo se abre a possibilidade de um diálogo, e consequentemente a prática da fé pode vir a ser uma experiência que promova a integração do seres humanos entre si e com o meio em que vivem.

Em sua compreensão do texto como mediação da compreensão de si, Ricoeur enfoca uma característica fundamental: o texto aponta para um além de si mesmo, não se encontra fechado sobre si mesmo e não pode ser compreendido como linguagem voltada sobre si mesma. Este para além de si mesmo que caracteriza o texto nos coloca diante de outra ideia central no pensamento de Ricoeur: ler um texto é, de certa maneira, considerar o seu autor como já morto e o livro como póstumo, e, quando o autor procura explicar sua obra, o faz na qualidade de leitor-intérprete da obra. A metáfora da morte do autor expressa a ideia da autonomia do texto, a vida própria 
para além da intenção de seu autor, ou seja, o texto transcende as condições psicológicas, sociais, históricas de sua produção. Por isso, um texto pode ser apropriado em outras situações por leitores distantes, a partir de um processo que envolve descontextualização e recontextualização. Como consequência, surge a ideia de que o distanciamento não é um obstáculo a ser superado, mas condição para a própria compreensão. E se a explicação da estrutura interna do texto é necessária, o é igualmente insuficiente, não conclusiva. Isto porque, a partir de sua estrutura, o texto abre o leitor a uma proposição de mundo, o mundo do texto, fazendo com que uma obra literária não possa ser compreendida como diálogo entre autor e leitor, mas sim entre leitor e intencionalidade do texto. É o que testemunham obras literárias que ainda hoje dizem algo a seus leitores, obras cujos autores e o contexto cultural ao qual pertenciam há muito desapareceram.

Assim, apropriar-se de um texto é apropriar-se dos vários mundos que o texto permite e incentiva a partir do seu potencial de sentido. O texto possui "um" sentido que não deixa de ser atualizado pelo leitor, e apropriar-se desse sentido é todo o contrário da celebração de um eu narcisista, é na verdade despojamento do próprio eu, uma vez que o texto fornece um "si mesmo" ao leitor, transformando-o em um si mesmo como outro. Assim, interpretamos e atualizamos um texto quando nos apropriamos de sua proposição de mundo, sem, contudo, conceber a apropriação como posse e sim como despojamento. Isto faz do ato de interpretar um risco, uma vez que significa expor-se a si mesmo por meio da leitura interpretativa a fim de habitar uma proposição de mundo. E nesse processo, nessa nova habitação possibilitada pela leitura do texto, o leitor se compreende melhor ou começa a se compreender. $\mathrm{O}$ leitor vem à leitura com sua pré-compreensão e suas conjecturas - muitas vezes não formuladas explicitamente - e à medida que avança na leitura do texto valida, refaz ou dá forma explícita às suas expectativas. Este processo hermenêutico desapropria duplamente o sujeito: primeiramente promove a desapropriação de si diante da objetividade da obra, no caso o mundo do texto, e em um segundo momento desaloja o sujeito de sua identidade primeira para abri-lo a novas possibilidades de ser-no-mundo.

E nessa apropriação do mundo do texto, o papel da tradição é fundamental, tanto no judaísmo como no cristianismo. Haja vista que, fora da comunidade viva dos intérpretes que cria e recria o texto pelo ato da leitura, o texto nada mais é que um cadáver entregue à autópsia de um simples 
método de análise estrutural que ignora, no corpo inerte, a face, o rosto, capaz de manifestar as marcas de uma história de vida. O texto é inseparável da comunidade viva de leitores, o que implica a abertura à maneira como se deu e se dá a recepção do texto ao longo da história que ele mesmo ajuda a tecer. Dizer inseparável não significa, contudo, que o texto não possa, ou melhor, não deva ser recontextualizado no mundo do leitor que o interpreta.

A apreensão do mundo do texto que possibilita uma nova maneira de ser-no-mundo não se reduz à linguagem cotidiana, às expressões humanas utilizadas em uma comunicação imediata. Essa apreensão acontece também a partir de um distanciamento que se instaura do real consigo mesmo, como o faz a ficção ao abrir a realidade cotidiana a novas possibilidades. Segundo Ricoeur, a linguagem ficcional expressa uma nova modalidade, a do poder-ser, na medida em que toma como essencial as variações imaginativas que a literatura possibilita. ${ }^{17} \mathrm{~A}$ ficção constitui-se, pois, como um caminho privilegiado para a refiguração do real, e a linguagem poética opera por excelência o que Aristóteles denominava por mímesis (imitação) da realidade. Com efeito, esta imitação da realidade só se torna possível porque a própria realidade é recriada, de tal modo que toca a essência mais profunda do ser humano.18

Portanto, a aplicação da hermenêutica ao campo do estudo teológico de ambas as tradições, mais especificamente na interpretação dos textos sagrados para as tradições judaica e cristã, é essencial para o entendimento da expressão de fé de cada uma e para a abertura a um profícuo diálogo inter-religioso. Entendimento e abertura possibilitados não pela reflexão direta sobre Deus, se é que isto é possível, mas sim sobre a linguagem que fala humanamente sobre Deus, como é o caso dos textos da Escritura Sagrada, a Torá e a Bíblia.

O teólogo francês Claude Geffré, ao retomar aspectos do pensamento de Paul Ricoeur, observa que a perspectiva hermenêutica é imprescindível para o exercício da ciência teológica, já que em sua própria particularidade é capaz de possibilitar um alcance universal, de modo que perpassa os séculos e até mesmo a diversidade de culturas. Ou seja, o exercício hermenêutico das Sagradas Escrituras faz com que uma mensagem ou um signo de um

17 Paul Ricoeur, Del texto a la acción, p. 107.

18 Ibid., p.108.

ReVISTA de Cultura TeOlógicA - V. 18 - N. 70 - ABR/JUN 2010 
determinado ethos social historicamente situado tenha significado relevante à outra cultura amplamente distinta em seu tempo e espaço, pelo fato de que a genuína mensagem do autor não se perde quando o leitor permite-se compreender ante a obra em seus aspectos históricos, sociológicos e linguísticos correlacionados à sua busca sensível e racional do conhecimento.

Desse modo, uma análise hermenêutica dessas duas tradições é um passo inicial no desenvolvimento dialógico e harmônico entre elas, conferindo e conservando em cada uma a integridade ética e teológica ante as inevitáveis mudanças e transformações morais e culturais no decorrer do processo histórico, ${ }^{19}$ visto que não se tratam de abstrações metafísicas, mas são representações profundas de uma experiência transcendental e dinâmica de distintos grupos culturais.

Tanto a hermenêutica rabínica quanto a hermenêutica cristã são singulares em seus métodos, processos e tradições interpretativas, apesar de possuírem em comum alguns textos, os do Primeiro Testamento. Também se constata que a interpretação dada por ambas advém de sua experiência social, política e cultural a partir dos contextos históricos em que nascem e se desenvolvem. Contudo, com o auxílio de Paul Ricoeur, pode-se afirmar que a compreensão desses textos, cada qual feita em seu tempo e contexto determinados, são passíveis de renovação a partir de quem neles penetra, uma vez que o texto escrito é autônomo no que tange ao contexto de sua elaboração e a intenção primeira de seu autor. Justamente porque o texto traz em si um para além de si mesmo, ou seja, um mundo possível de ser habitado, de ser apropriado, que desapropria o leitor de sua identidade primeira para abri-lo a novas possibilidades de ser-no-mundo.

Desse modo, a compreensão de um texto pode variar com a cultura, a temporalidade e o enfoque pedagógico oriundo da interpretação, mas a finalidade do texto em sua mensagem genuína é resguardada. Isso aponta para um ponto de intersecção entre as religiões do Livro, ou seja, embora por meios interpretativos distintos, ambas coincidem em sua intencionalidade religiosa: a mensagem de salvação revelada por Deus e dita em linguagem humana.

19 Claude GefFrÉ, Crer e interpretar, pp. 31-33. 
A partir da perspectiva da hermenêutica filosófica desenvolvida por Ricoeur, é possível dizer que cada ser humano se constitui como um eu que é linguagem, de modo que, para conhecer-se a si mesmo, o ser humano identifica-se por meio de sua linguagem, reconhecida por seus signos e símbolos, e é só a partir dessa linguagem que ele se torna capaz de compreender o mundo no qual vive. E para compreender é preciso interpretar. É interpretando que o ser humano se realiza e se relaciona. ${ }^{20}$ Todavia, esse ser de linguagem não é inteiramente transparente a si mesmo, ou melhor, na linguagem de Ricoeur trata-se de um sujeito que é um "cogito ferido", um sujeito de ação e linguagem, ético e temporal. Trata-se do exame de si mesmo como outro, aberto ao outro, mediado pela linguagem e presente no mundo. Assim, um dos aspectos significativos do pensamento de Ricoeur diz respeito à ideia de que a alteridade é o caminho mais curto e mais adequado para a construção da própria identidade, ou seja, descobrir-se a si mesmo é aceitar-se como um outro, interpelado por um outro, muitas vezes diferente de mim.

O sujeito é atravessado e constituído pela alteridade, jamais transparente e com acesso imediato a si mesmo, sendo, em certo sentido, estranho a si mesmo. Além disso, o sujeito não é jamais ponto de partida - absoluto -, um "eu" dado a priori, mas um si mesmo como ponto de chegada de um longo percurso no qual retoma de forma reflexiva suas ações e criações. Ponto de chegada que é sempre um recomeço e um ponto de partida. A identidade desse si mesmo que somos é, portanto, ética, pois o reconhecimento de si acontece no reconhecimento do outro e no reconhecimento de si pelo outro, reciprocidade de reconhecimento que marca a forma de presença do outro na vida do sujeito. E esse reconhecimento do outro não acontece em um conhecimento objetivo do outro e nem de si mesmo, mas em um encontro de horizontes, no qual o meu horizonte (o meu ser-no-mundo) pode ser alargado ou retraído. A identidade narrativa é a identidade de um sujeito que só pode ser compreendido como um ser aberto, atravessado e constituído por uma série de mediações e desdobramentos no tempo, sujeito inserido no tempo e em uma história que o atravessa e o ultrapassa.

Desse modo, é cabível afirmar que, para que haja uma autêntica hermenêutica teológica, é necessário um mergulho no mundo do texto; no

20 Davi LeVY, A identidade narrativa, pp. 51-57. 
qual o homem, compreendendo-se ante a obra, torna-se capaz de construir sua própria identidade sem perder-se de si mesmo, afirmando-se como um fidedigno ser humano capaz de articular um diálogo com o seu tempo e com sua história. Daí tem-se a constatação da necessidade de um diálogo fecundo que promova o respeito pela a alteridade e a partir dela evoque o reconhecimento do outro como ser capaz de se expressar segundo sua maneira de compreender e interpretar o mundo e a história que ajuda construir.

É por meio do enfoque das tradições interpretativas que se pode estabelecer um diálogo que proporcione um melhor convívio da humanidade. Desde o Talmude, a hermenêutica rabínica nos propõe a leitura dos textos sagrados a partir de uma experiência ético/moral arraigada na tradição; do ponto de vista da tradição cristã surge a proposta de interpretar a Sagrada Escritura inserindo-se em uma profunda análise histórico-crítica, fazendo uso de vários instrumentais linguísticos e científicos.

De acordo com o teólogo Nilo Ribeiro Jr., que tem como referência as obras de Emmanuel Lévinas, "os talmudistas têm a preocupação de ler os versículos bíblicos para além do sentido imediato, embora sem negar o contato com a materialidade do texto". ${ }^{21}$ Desta maneira, o que mais importa é o sentido ético que os textos expressam, tendo como referência última de interpretação dos versículos a responsabilidade do ser humano diante do outro. Ou seja, a revelação por meio das letras, dos textos, não se resume apenas a uma ética-moral kantiana, mas é detentora de um caráter profético, a chave de leitura é o sujeito que se sente incessantemente interpelado pelo outro, e, por essa mesma analogia, se dá a relação humana com Deus assim como a relação de Deus para com o ser humano. Já Ricoeur opta por um modelo poético, com o qual evita que as modalidades de linguagens bíblicas sejam reduzidas à profecia, já que, como afirma Nilo Ribeiro Jr., para Ricoeur "o profético é a modalidade de linguagem que mais facilmente dá margem a uma concepção insuficiente ou unívoca de inspiração". ${ }^{22}$ Todavia, Nilo Ribeiro Jr. afirma que Ricoeur, a fim de negar totalmente o modelo prescritivo de Lévinas, admite a necessidade de "associá-lo aos outros gêneros

\footnotetext{
21 Nilo RibeiRo Jr., Sabedoria e Paz, p. 145.

22 Ibid., p. 147.
} 
que não se dirigem à vontade para submetê-la, mas à imaginação, já que esses gêneros abrem ao leitor um mundo novo do texto". ${ }^{23}$

Embora, existam divergências entre os enfoques e métodos das tradições judaica e cristã, pode-se, contudo, constatar que existe a possibilidade de convivência mútua satisfatória entre tais tradições, na qual ocorra uma genuína interação e superação de problemas históricos, se ambas se esforçarem por manter um atitude inclusivista de uma cultura com relação a outra, de modo a enfocar sempre o respeito, a solidariedade e a liberdade, sem suprimir a identidade própria a cada tradição. Na inter-relação entre as culturas, cabe, no entanto, a cada uma se esforçar para que esse relacionamento seja pacífico ou menos conflituoso. Isso porque na busca por uma convivência pacífica entre as culturas, as tradições religiosas assumem um importante papel, como é o caso, hoje, das tradições judaica e cristã.

\section{VISLUMBRANDO PERSPECTIVAS...}

Todo processo dialógico requer a árdua tarefa de interação e conhecimento, mesmo que a priori não se aceitem as ideias e posições alheias. Para construir uma sociedade com o mínimo de equilíbrio, é preciso que haja o diálogo genuíno entre as diversas tradições, cuja efetivação não signifique a perda da identidade dos interlocutores, mas sim o mútuo enriquecimento por meio das interpelações e ideias apreendidas daquele que tem uma perspectiva distinta, porém não necessariamente contrária.

A hermenêutica teológica pode ser um meio eficaz para o incentivo ao diálogo entre judeus e cristãos, já que ela pode evidenciar os pontos correlativos entre essas duas grandes tradições religiosas, contribuindo desta maneira para a construção de uma sociedade mais tolerante e pacificadora. Contudo, esse processo não é fácil; requer aplicação dos estudos científicos, no caso, a hermenêutica, bem como um intenso dispor ético de ambas as partes envolvidas, cristãos e judeus. É evidente que essas tradições têm muito a oferecer no campo da integração do humano, pois esboçam, por meio de sua história, a preocupação em salvaguardar os valores éticos e em valorizar o ser humano e seu meio natural; com a finalidade de garantir satisfatoriamente a plenitude da vida que na profissão de fé de ambas é

23 Ibid., p. 148.

ReVISTA de Cultura TeOlógICA - V. 18 - N. 70 - ABR/JUN 2010 
garantida pelo mesmo Deus, gerador da vida e parceiro do ser humano em sua manutenção e aprimoramento.

Contudo, é preciso que se compreenda que o processo hermenêutico na construção de uma identidade religiosa não significa a definição da "meIhor" interpretação do texto sagrado, ou de "quem" vai interpretá-lo com mais exatidão, configurando assim uma disputa que leva à discórdia e à negação do outro. Trata-se, como foi dito ao longo deste ensaio, de averiguar o que uma corrente interpretativa pode ajudar no processo de desenvolvimento da outra em sua relação com o mundo e o meio em que vive. Tanto a Tradição judaica quanto a cristã precisam entender que estar diante do diferente pode significar a rica possibilidade de uma releitura dos fundamentos da própria fé que, consequentemente, ajude a uma interpretação da identidade que dessa fé emana. Além disso, devem compreender que estar diante do diferente, muito mais que significar uma ameaça, pode vir a ser a possibilidade de uma nova percepção da identidade religiosa entendida como uma identidade em contínua construção a partir da releitura de textos fundadores.

\section{REFERÊNCIAS BIBLIOGRÁFICAS}

Barrera, J. T. A bíblia judaica e a bíblia cristã. Introdução à história da Bíblia. Petrópolis: Vozes, 1995.

Barrera, J. T. Os Homens de Qumran: literatura, estrutura e concepções religiosas. Petrópolis: Vozes, 1996.

Gentil, H. S. Para uma poética da modernidade. Uma aproximação à arte do romance em Temps et Récit de Paul Ricoeur. São Paulo: Loyola, 2005.

Geffré, C. Crer e interpretar: a virada hermenêutica da teologia. Petrópolis: Vozes, 2004.

Levy, D. A identidade narrativa: conhecer o si-mesmo é narrar sua história. Mente-Cérebro. 11. ed. São Paulo: Duetto Editorial, 2008.

Mckenzie, J. Dicionário Bíblico. São Paulo: Paulinas, 1999.

Ribeiro Jr., N. Sabedoria e Paz - ética e Teo-lógica em Emmanuel Lévinas. São Paulo: Loyola, 2008.

Ricoeur, P. Del texto a la acción: ensayos de hermeneutica II. México: Fundo de Cultura Econômica, 2002. 